\title{
The influence of size on striped bass foraging
}

\author{
K. J. Hartman* \\ West Virginia University, Wildlife and Fisheries Resources Program, Division of Forestry, PO Box 6125, Morgantown, \\ West Virginia 26506-6125, USA
}

\begin{abstract}
Striped bass Morone saxatilis is an abundant piscivorous fish in estuaries and coastal systems along the US Atlantic coast and has also been stocked into systems in California and the continental US. Despite the widespread distribution of striped bass and their relative importance as a predator in these systems, little is known about how relative size of prey affects their prey capture success. This study measured the capture success and handling times of striped bass fed live shiners Notropis atherinoides and $N$. chrysocephalus and the results are expressed in terms of size (prey-to-predator size ratio, PPR). Striped bass capture success declined with increasing PPR. It was best described ( $p<$ 0.01 ) by the equation: attack success $=0.861-1.82 \mathrm{PPR}$. Handling time $(h)$ increased with increasing PPR $\left(p<0.01\right.$ ) and was described by the equation: $h=0.339 \mathrm{e}^{11.9 P P R}$. Comparison of prey profitability curves showed that the relative size of prey suggested as most profitable (mass/time) was similar to that found in the stomachs of wild striped bass in Chesapeake Bay from 1990 to 1992. The peak in frequency of PPR from stomachs occurred at PPR $=0.12$ (mean PPR $=0.14$ ) and was identical to the peak in profitability from model results (PPR $=0.12$ ), although both the diet PPR and model profitability distributions were skewed towards larger relative prey sizes. Comparison of the results of this study with a similar study for small bluefish suggests that profitable prey sizes for striped bass overlap with those of much smaller bluefish.
\end{abstract}

KEY WORDS: Striped bass · Foraging · Attack success - Capture success - Handling time

\section{INTRODUCTION}

Striped bass Morone saxatilis is a species of ecological and economic importance in California, along the eastern coast and inland systems of the United States. These fish are top predators in coastal systems, feeding on aquatic invertebrates at small sizes, but generally becoming more piscivorous with age (Boynton et al 1981, Gardinier and Hoff 1982, Rulifson \& McKenna 1987, Hartman \& Brandt 1995a). Further, striped bass may be important in controlling populations of prey species (Hartman \& Brandt 1995b) and shortages of appropriate-sized food have been suggested as a reason for coastal migration of adult striped bass in Chesapeake Bay (Hartman 1993). Recently, a high incidence of disease and lesions in Chesapeake Bay striped bass have been correlated with poor physical condition and possible prey shortages for striped bass (E. May, Mary-

\footnotetext{
•E-mail: hartman@wvu.edu
}

land Department of Natural Resources, pers. comm.), and negative correlation between population abundance of striped bass and bluefish Pomatomus saltatrix has led agencies to become concerned that competitive or other interactions between striped bass and bluefish may serve to regulate coast-wide abundance of these species (see National Marine Fisheries Service request for proposals, November, 1997). As the nature of any relationship between striped bass and bluefish abundances may be related to predator-prey interactions and competition for food, knowledge of the foraging ability of striped bass is important in order to evaluate their potential for competition with other species and in assessing their relative role in structuring prey populations.

Little is known about the relative foraging behavior of striped bass. Although the diet of this species has been described in many systems and for many sizes or ages of fish (see Setzler-Hamilton \& Hall 1991 for a review), little is known about the role that predator and prey size relationships play in foraging of striped bass. 
Given the importance of striped bass in aquatic systems and the lack of data on their foraging dynamics, the objective of this study was to measure their foraging parameters (i.e. handling time and capture success). Due to the importance of size in predator-prey interactions (e.g. Confer et al. 1990, Rice et al. 1993, Wright et al. 1993, Scharf et al. 1998) the foraging parameters were estimated across a range of prey-to-predator size ratios (PPR) to evaluate prey profitability in light of field measures of prey size from diet analysis.

\section{METHODS}

Evaluation of the foraging dynamics of striped bass was done using laboratory experiments, with the resulting prey profitability compared to field data of sizes of prey eaten by striped bass. Laboratory experiments were conducted to determine the attack success and handling times of striped bass feeding on a wide range of prey sizes. Statistical models of these foraging relationships were combined to estimate prey profitability of different sized prey to striped bass predation. Estimates of prey profitability were then compared with actual measures of the prey frequency distributions across a range of PPR from field diet collections.

Laboratory experiments. Age-0 striped bass (Hudson River origin) were obtained from the Indian Point, New York, fish hatchery and reared to a size between 300 and $400 \mathrm{~mm}$ total length (TL) at the Great Lakes Center (GLC) fish holding facility in Buffalo, New York. Fish were fed commercial pellet food until they attained a size of approximately $250 \mathrm{~mm}$ TL. Thereafter, fish were maintained on a diet of live emerald shiners Notropis atherinoides and striped shiners $N$ chrysocephalus obtained from local bait distributors. These shiners are not a natural prey of striped bass in most systems, but are of a similar morphometry to natural prey such as Atlantic silversides Menidia menidia and bay anchovy Anchoa mitchilli.

Foraging experiments with striped bass were conducted during spring and summer 1996 at the GLC fish Iab. Fish were held at 19 to $20^{\circ} \mathrm{C}$ and light cycles were set at $14 \mathrm{~h}$ light: $10 \mathrm{~h}$ dark throughout the experiments. Experiments were run in a large, round tank $1.5 \mathrm{~m}$ high and $2.5 \mathrm{~m}$ in diameter) with a light-colored (offwhite) background to maximize contrast between striped bass, prey, and the tanks. This high contrast was necessary for determining capture success from video replay. A standpipe on the tank side permitted a flow-through water supply of de-chlorinated Buffalo city water.

Foraging experiments were conducted with groups of striped bass fed live shiners once daily. The ensuing foraging by striped bass was monitored and recorded on video tape for later frame-by-frame review of each trial (Juanes 1992). At the beginning of an experiment a group of 3 striped bass of similar length (mean $340 \mathrm{~mm} \mathrm{TL} \pm 10 \%$ ) were introduced into the test tank and allowed to acclimate to the new tank for $24 \mathrm{~h}$. This acclimation period also constituted a fasting period which ensured feeding motivation. To start a trial, 8 to 10 shiners of similar length (within $4 \mathrm{~mm}$ of each other, e.g. 80 to $84 \mathrm{~mm} \mathrm{TL)} \mathrm{were} \mathrm{measured} \mathrm{and} \mathrm{introduced}$ into the test tank from a floated $3 \mathrm{l}$ carboy that was tipped to release the shiners. Striped bass were allowed to feed on the shiners until all prey were eaten or for $1 \mathrm{~h}$, with all foraging activities recorded on VCR tape from a point directly above the tank. After each trial the video tape was reviewed frame-by-frame and the number of attacks and captures recorded.

The handling time for a prey was considered the length of time from successful capture until the striped bass ceased swallowing activity (gulping and flaring of gills). Handling time was not measured in all instances due to difficulty in determining when swallowing had occurred. After each trial, the striped bass were anesthetized with MS-222, their lengths were re-measured for PPR and they were then returned to a holding tank. Striped bass were replaced with another randomly selected group of $3 \mathrm{fish}$ and the same acclimation and experimentation procedure followed for the next trial. This replacement procedure was used to minimize learning of fish from continuous holding in the experimental tanks (Scharf et al. 1998). A total of 17 trials were run with different combinations of 3 striped bass and PPR ranging from 0.08 to 0.56 .

Predicted prey profitability. Profitability of different PPR was calculated by combining the attack success and handling time equations from laboratory experiments with predator and prey weights. Profitability $(P)$ was defined as:

$$
P=W_{\text {prey }} \cdot W_{\mathrm{sb}}^{-1} \cdot \text { handling time } e^{-1} \cdot \mathrm{CS}
$$

where $W_{\text {prey }}$ is the weight $(g)$ of the prey fish, $W_{\mathrm{sb}}$ is the weight $(\mathrm{g})$ of the striped bass, and CS is the capture success, or proportion of striped bass attacks that resulted in ingestion of prey (Scharf et al. 1998). Individual weights of shiners were not taken during the trials to minimize handling and stress in the prey which may have influenced prey responsiveness and biased the foraging results. Therefore, $W_{\text {prey }}$ for this equation was calculated from mean shiner length for each trial based on a Lake Erie emerald shiner length-weight equation $\left[\log _{10} \mathrm{WW}=2.976 \log _{10}\right.$ TL -5.17 ; from HaItman \& Margraf 1992]. In this paper, I calculated the prey profitability for a $412 \mathrm{~g}$ striped bass, the mean weight of fish used in experiments. 
Field data on PPR. Field data on the PPR of wild striped bass were obtained by analysis of striped bass diet information from fish collected between January 1990 and March 1992 from the mid-Chesapeake Bay and several tributaries (for further details on collections and diets see Hartman \& Brandt 1995a). Prey lengths were pooled across seasons and only prey length data from striped bass of 300 to $400 \mathrm{~mm}$ TL were included in the analysis. For each prey in the diet data set, PPR was determined by dividing prey fish length by the total length of the striped bass. The resulting PPR distributions and summary statistics provide a measure of the actual PPR used by fish in the field, which can be compared with predicted prey profitability to evaluate how well the foraging parameters reflect field foraging activities.

\section{RESULTS}

\section{Striped bass foraging experiments}

Capture success (CS) of striped bass declined with increasing PPR. The relationship between CS and PPR could best be described by the linear equation

$$
\mathrm{CS}=0.861-1.82 \mathrm{PPR}
$$

$\left(\mathrm{N}=17, \mathrm{r}^{2}=0.754, \mathrm{p}<0.01\right)$. The largest prey a striped bass could successfully feed on was slightly larger than $40 \%$ of the length of the predator (Fig. 1). This upper prey size was verified in a trial by feeding the striped bass striped shiners with PPR of 0.559 . This was the only trial in which striped shiners and not emerald shiners were used and this trial was not included in data used for regression analysis. This verification was

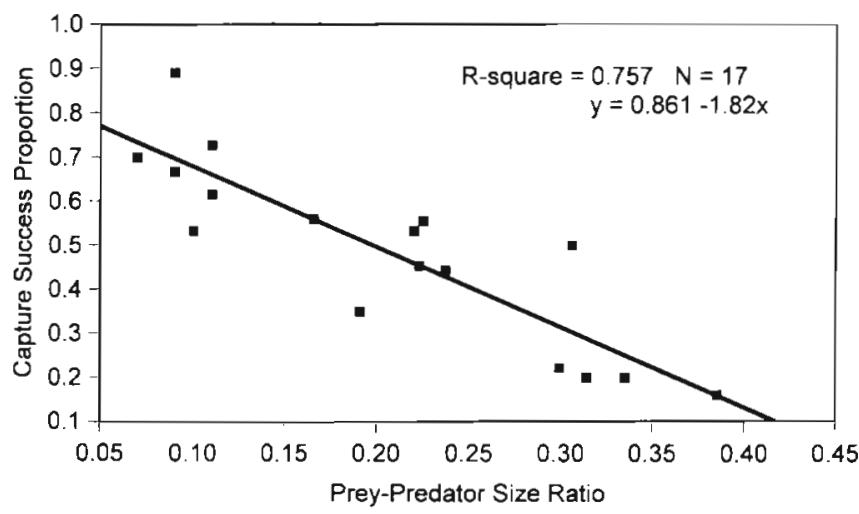

Fig. 1. Capture success proportion (no. of captures/no. of attacks) for striped bass Morone saxatilis fed live emerald shiners Notropis atherinoides in relation to prey-predator size (length) ratios

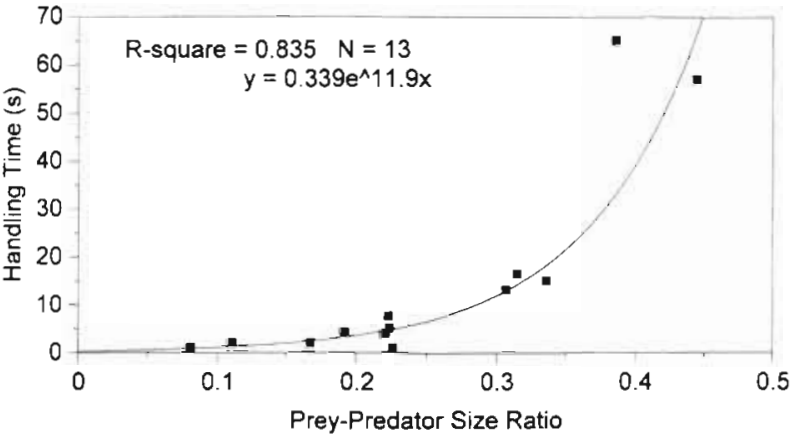

Fig. 2. Handling time (s) of striped bass Morone saxatilis fed emerald shiners Notropis atherinoides in relation to preypredator size (length) ratios. Handling time is defined as the time from point of capture until the fish ceases swallowing activity

not possible with emerald shiners, which do not attain this length (190 $\mathrm{mm}$ TL). In this trial, although the striped shiners were battered and missing scales, none of these shiners were consumed during a $24 \mathrm{~h}$ trial.

Handling time for striped bass feeding on shiners increased with increasing PPR (Fig. 2). The relationship between PPR and handling time(s) was fit (least squares) using an exponential function $\left(\mathrm{N}=13, \mathrm{r}^{2}=\right.$ 0.835, $\mathrm{p}<0.01$ ):

$$
h=0.339 e^{11.9 P P R}
$$

\section{Profitability versus diet PPR}

The profitability of different sized prey (relative to striped bass) was similar to the prey frequencies across the range of PPR observed in the stomachs of wild striped bass (Fig. 3). Based upon statistical foraging models developed from the laboratory experiments, the peak profitability occurred at a PPR of 0.12 , coinciding with the peak frequency of prey in Chesapeake Bay striped bass stomachs (peak $=0.12$, mean $=0.14$, $\mathrm{SD}=0.092, \mathrm{~N}=788$ ). Distributions of relative prey frequencies from the stomachs and from the prey profitability curve deviated from a normal curve. Both the prey frequency and prey profitability were skewed towards larger PPR, but PPR distribution from stomachs was slightly more skewed towards larger relative prey size (Fig. 3).

\section{DISCUSSION}

Striped bass do not feed on all sizes of prey equally well. Small prey are more vulnerable to attack by striped bass (higher capture success and shorter handling time). However, using a criteria of $75 \%$ of maxi- 


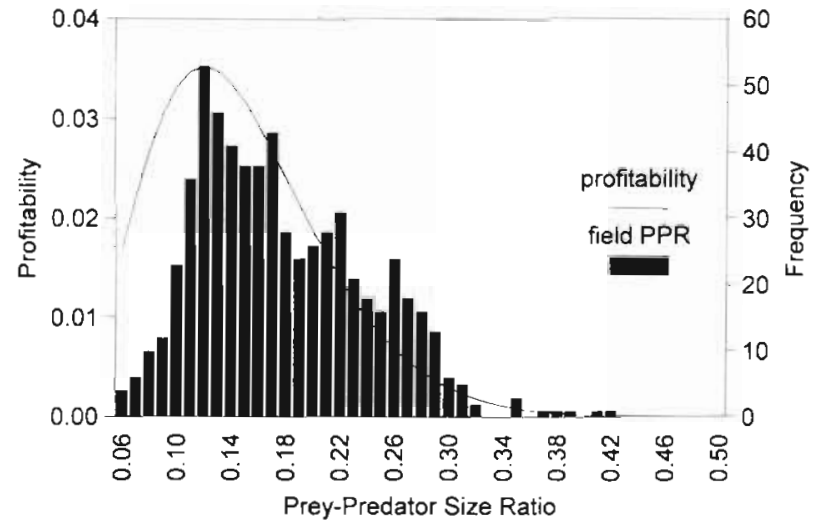

Fig. 3. Comparison of the prey profitability derived from laboratory experiments on the size-specific capture success and handling time of striped bass (solid line) with the frequencies of prey observed across a range of prey-predator size ratios in 300 to $400 \mathrm{~mm}$ TL striped bass stomachs in Chesapeake Bay during 1990 to 1992 (vertical bars)

mum profitability values as most profitable, prey of 7 to $18 \%$ of striped bass length were most profitable. Capture success (proportion of attacks that result in ingestion) declined with increasing PPR. Handling times increased with increasing PPR. The combination of these 2 foraging parameters shows that prey become increasingly less vulnerable to striped bass predation as relative size increases.

The findings that prey become less vulnerable to predation as their relative size increases is not surprising. Many studies have shown the value of increased size upon the ability to avoid predation (e.g. Bailey \& Houde 1989, Margulies 1990, Witting \& Able 1993, Gleason \& Bengtson 1996) and the declining mortality rate of larval and juvenile fishes is believed to be due at least in part to declining risk of predation (Bailey \& Houde 1989, Cowan \& Houde 1992).

Comparison of the prey profitability curves for striped bass with prey frequency distributions from striped bass stomachs indicated Chesapeake Bay striped bass generally fed in accordance with foraging model predictions. The peak in prey profitability curves coincided with the highest frequency of prey in the diets. Both profitability and diet prey frequency distributions were skewed towards larger relative prey sizes; however diet. frequency favored slightiy larger PPRs than suggested by the profitabilty curve.

This subtle difference between foraging model predictions and field PPRs may be due to a number of reasons or assumptions. First, the foraging parameters for striped bass upon which the prey profitability curve is based were developed using a single prey species and one that was not found in the Chesapeake Bay diets. Previous studies have shown minor differences in the morphology or behavior of prey can greatly alter for- aging dynamics (Werner \& Gilliam 1984, Wahl \& Stein 1988, Scharf et al. 1998). Differences between diet PPRs and prey profitability curves may be due solely to differences in the species upon which wild striped bass feed or differences in the relative abundance of these different species. Thus, results of this study may have been different had they been conducted with a different prey which are more difficult to capture. However, the similarity of PPR distributions between field samples from stomachs and the profitability model are striking considering the suite of different prey fed upon by striped bass in the field study (spot Leiostomus xanthurus, Atlantic croaker Micropogonius undulatus, Atlantic menhaden Breevortia tyrannus, bay anchovy, and Atlantic silversides; Hartman \& Brandt 1995a).

Striped bass prey vulnerability does differ dramatically from the sympatric bluefish. Scharf et al. (1998) found that 80 to $155 \mathrm{~mm}$ TL bluefish could successfully feed upon Atlantic silversides (a species morphologically similar to the shiners used in this study) up to a prey of length $63 \%$ of that of the predator. Striped bass were unable to consume shiners that were $56 \%$ of the predator length and capture success was less than $20 \%$ for prey exceeding $35 \%$ of the predator length. Much of this apparent difference in feeding ability between striped bass (this study) and bluefish (Scharf et al. 1998) may be due to the bluefish's searing dentition. Searing dentition permits bluefish to disable and consume prey without needing to swallow them whole as striped bass must do

However, further differences may arise due to the fact that striped bass in this study were larger than bluefish used in the Scharf et al. (1998) study. Differences in predator sizes would result in different prey sizes for a given PPR. For example, a PPR of 0.40 for bluefish may represent a prey length of $47 \mathrm{~mm} \mathrm{TL}$ (based upon a mean bluefish size of $118 \mathrm{~mm} \mathrm{TL}$ ) while a striped bass PPR of 0.40 would represent a prey length of $136 \mathrm{~mm}$ TL. As striped bass and bluefish are suggested as potential competitors, it is tempting to compare the results of foraging experiments by Scharf et al. (1998) for bluefish with the present results for striped bass. However, differences in absolute predator and prey sizes between the 2 studies may weaken comparisons.

There were interesting differences in the shape of the prey profitability curves between striped bass and bluefish. In the Scharf et al. (1998) study, prey profitability curves were dome-shaped with near maximal profitability over a wide range of PPR. For striped bass, the profitability curve was steeply-sloped, but was skewed towards larger PPR. This steep-sloped piofitability curve for striped bass relative to the wide, dome-shaped profitability curve for bluefish can probably be explained by the searing dentition in bluefish. 
Gape width is another possible explanation for differences in the profitability curves. No published gape measurements are available for these $2 \mathrm{fish}$, but based on personal observations they likely favor striped bass, which would not explain the differences in profitability curves between the species.

In the Chesapeake Bay, striped bass and bluefish of the sizes used in experiments (this study and Scharf et al. 1998) typically overlap in both diet composition and spatial distribution (Hartman \& Brandt 1995a). Thus, comparing prey profitability for striped bass feeding on shiners with that of bluefish feeding on the morphometrically similar Atlantic silversides provides a basis for comparison of the relative foraging range of each species. For the average striped bass $(340 \mathrm{~mm} \mathrm{TL})$, the peak of the prey profitability curve occurs at a prey length of $41 \mathrm{~mm}$ TL (PPR =0.12), while for the median bluefish (118 mm TL) in the Scharf et al. (1998) study, the peak of the prey profitability curve occurs at a prey length of $71 \mathrm{~mm}$ TL. Thus, although the bluefish was much smaller than the striped bass in this comparison, the optimum prey size for the bluefish is roughly twice as large as for the striped bass. This suggests that the absolute prey size spectrum of striped bass overlaps with much smaller bluefish. Thus, within a system, shortages of small prey may have a large influence on striped bass feeding success, but will have lesser effects on bluefish.

The analysis of the relative foraging abilities of striped bass provides a useful addition to the growing literature on foraging in piscivorous fish. Although foraging parameters have been published for some piscivores (Werner 1977, Major 1978, Webb \& Skadsen 1980, Webb 1982, Horwick \& O'Brien 1983), this represents one of only a few contributions (Major 1978, Wahl \& Stein 1988, Juanes 1994, Scharf et al. 1998) for temperate estuarine and marine species. These data and comparisons of foraging abilities should be useful for future models of trophic interactions in estuarine and coastal systems.

Acknowledgements. I am grateful to D. Mason and 3 anonymous referees for reviewing earlier versions of this manuscript and providing helpful comments that improved this submission. This paper is published with the approval of the Director of the West Virginia Agricultural and Forestry Experiment Station as Scientific Article No. 2730.

\section{LITERATURE CITED}

Bailey KM. Houde ED (1989) Predation on eggs and larvae of marine fishes and the recruitment problem. Adv Mar Biol 25:1-83

Boynton WR, Polgar TT, Zion HH (1981) Importance of juvenile striped bass food habits in the Potomac Estuary. Trans Am Fish Soc 110:56-63

Confer JL, Mills EL, O'Bryan L (1990) The influence of prey abundance on species and size selection by young yellow perch (Perca flavescens). Can J Fish Aquat Sci 47:882-887

Cowan JH Jr, Houde ED (1992) Size-dependent predation on marine fish larvae by Ctenophores, Scyphomedusae, and planktivorous fish. Fish Oceanogr 1(2):113-126

Gardinier MN, Hoff TB (1982) Diet of striped bass in the Hudson River Estuary. NY Fish Game J 29:152-165

Gleason TR, Bengtson DA (1996) Growth, survival and sizeselective predation mortality of larval and juvenile inland silversides, Menidia beryllina (Pisces: Atherinidae). J Exp Mar Biol Ecol 199:165-177

Hartman KJ (1993) Striped bass, bluefish, and weakfish in the Chesapeake Bay: energetics, trophic linkages, and bioenergetics model applications. PhD dissertation, University of Maryland, College Park

Hartman KJ, Brandt SB (1995a) Trophic resource partitioning diets, and growth of sympatric estuarine predators. Trans Am Fish Soc 124:520-537

Hartman KJ, Brandt SB (1995b) Predatory demand and impact of striped bass, bluefish, and weakfish in the Chesapeake Bay: applications of bioenergetics models. Can J Fish Aquat Sci 52:1667-1687

Hartman KJ, Margraf FJ (1992) Effects of prey and predator abundances on prey consumption and growth of walleyes in western Lake Erie. Trans Am Fish Soc 121:245-260

Horwick GL, O'Brien WJ (1983) Piscivorous feeding behaviour of largemouth bass: an experimental analysis. Trans Am Fish Soc 112:508-516

Juanes $F$ (1992) The advantages of advection: recruitment, piscivory, growth, and consumption of young-of-the-year bluefish (Pomatomus saltatrix). PhD Dissertation, Marine Science Resource Center, State Univ of NY, Stoneybrook

Juanes F (1994) What determines prey size selectivity in piscivorous fishes? In: Stouder DJ, Fresh KL, Feller RJ (eds) Theory and application in fish feeding ecology. Univ of South Carolina Press, Columbia, p 79-100

Major PF (1978) Predator-prey interactions in two schooling fishes, Caranx ignobilis and Stolephorus purpureus. Anim Behav 26:760-777

Margulies D (1990) Vulnerability of larval white perch, Morone americana, to fish predation. Environ Biol Fish $27: 187-200$

Rice JA, Crowder LB, Rose KA (1993) Interactions between size-structured predator and prey populations: experimental test and model comparison. Trans Am Fish Soc 122:481-491

Rulifson RA, McKenna SA (1987) Food of striped bass in the Upper Bay of Fundy, Canada. Trans Am Fish Soc 116: $119-122$

Scharf FS, Buckel JA, Juanes F, Conover DO (1998) Predation by juvenile piscivorous bluefish (Pomatomus saltatrix): the influence of prey to predator size ratio and prey type on predator capture success and prey profitability. Can J Fish Aquat Sci 55:1695-1703

Setzler-Hamilton EM, Hall L Jr (1991) Striped bass Morone saxatilis. In: Funderburk SL, Mihursky JA, Jordan SJ, Riley D (eds) Habitat requirements for Chesapeake Bay living resources. Chesapeake Research Consortium, Annapolis, MD, p 13-1-13-25

Wahl DH, Stein RA (1988) Selective predation by three esocids: the role of prey behavior and morphology. Trans Am Fish Soc 117:142-151

Webb PW (1982) Avoidance responses of fathead minnow to strikes by four teleost predators. J Comp Phys A 147: 371-378

Webb PW, Skadsen JM (1980) Strike tactics of Esox. Can J Zool 58:1462-1469 
Werner EE (1977) Species packing and niche complementarity in three sunfishes. Am Nat 111:553-578

Werner EE, Gilliam JF (1984) The ontogenetic niche and species interactions in size-structured populations. Annu Rev Ecol Syst 15:393-426

Witting DA, Able KW (1993) Effects of body size on probabil-

Editorial responsibility: Kenneth Sherman (Contributing Editor), Narragansett, Rhode Island, USA ity of predation for juvenile summer and winter flounder based on laboratory experiments. Fish Bull US 91:577-581

Wright RA, Crowder LB, Martin TH (1993) The effects of predation on the survival and size-distribution of estuarine fishes: an experimental approach. Environ Biol Fish 36 : $291-300$

Submitted: March 22, 1999; Accepted: August 25, 1999 Proofs received from author(s): February 21, 2000 